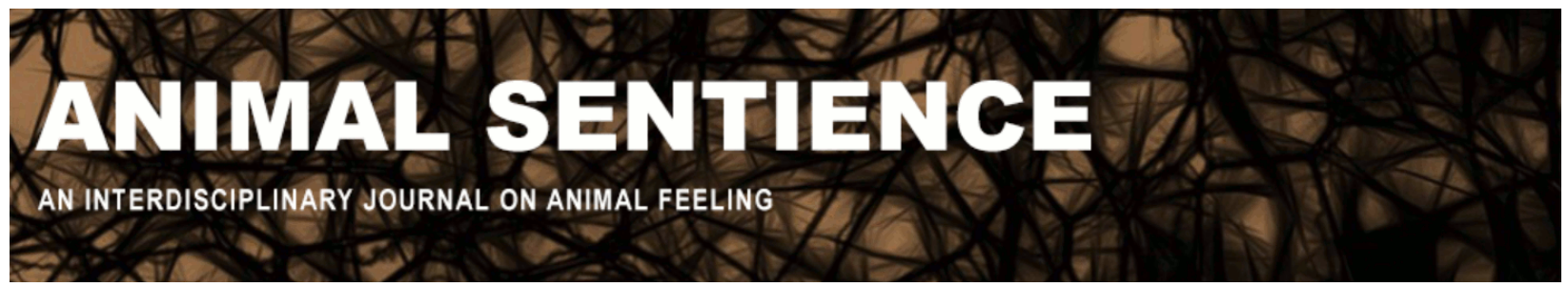

Freeman, Carrie P. (2017) Misperceiving and underestimating the ubiquitous chicken. Animal Sentience 17(7)

DOI: $10.51291 / 2377-7478.1251$

Date of submission: 2017-11-12

Date of acceptance: 2017-11-13

(c)

This article has appeared in the journal Animal

Sentience, a peer-reviewed journal on animal

cognition and feeling. It has been made open access,

free for all, by WellBeing International and deposited

in the WBI Studies Repository. For more information,

please contact

wbisr-info@wellbeingintl.org.

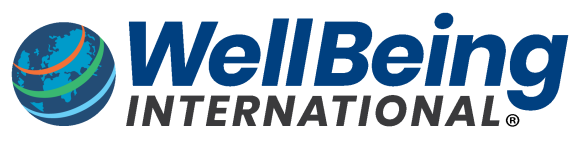

SOLUTIONS FOR PEOPLE, ANIMALS AND ENVIRONMENT 


\title{
Misperceiving and underestimating the ubiquitous chicken
}

\author{
Commentary on Marino on Thinking Chickens
}

\author{
Carrie P. Freeman \\ Department of Communication \\ Georgia State University
}

\begin{abstract}
Marino has provided an accurate and nuanced view about chickens' complex capabilities as sentient individuals. I explore the implications of these findings for scholars as well as for activists in the protection of farmed animals.
\end{abstract}

Carrie P. Freeman publishes on media ethics, activist communication, environmental communication, and critical animal studies. In 2014, she published the vegan advocacy book Framing Farming: Communication Strategies for Animal Rights. She co-authored the www.animalsandmedia.org style guide for responsible representations of animals. works.bepress.com/carrie_freeman/

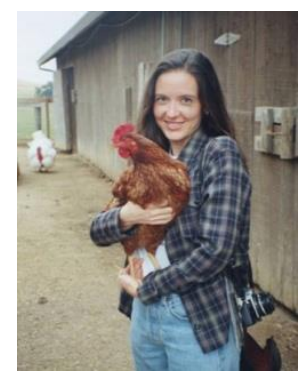

Whose (inconvenient) truth about chickens? Even readers uninterested in chickens per se will learn much about animal sentience from Marino's (2017) many scholarly examples and her knowledge of the scientific debates on how chickens' capacities to do and feel compare to those of other animals, including humans. In her detailed review, Marino indicates which species likely or conclusively possess the cognitive and behavioral abilities that have been investigated. Where studies have not been conducted with chickens but with other birds, Marino explains whether and why we can infer some similarities. She also acknowledges that there is variation within each species: each chicken is an individual and cannot be fully encompassed by any study. For readers who want more examples of individual chickens' stories, see the anecdotal evidence Davis (2012), President of United Poultry Concerns, describes from her years of experience living among chickens at her sanctuary.

Marino reviews studies that are now being done in support of chickens, to genuinely understand them better rather than experimenting on them by agricultural science departments for administrative/profit purposes. Writing about knowledge, truth, and power, Foucault (1980) recommends we notice what type of knowledge gets produced and gains the power of truth, and how it then functions within a larger framework of truth that institutions maintain in the service of their own interests. Funding for critical animal studies on behalf of animals is hard to come by, unlike funding on behalf of animal industries. Hence the latter is likely to produce more findings that influence how we view and value chickens (primarily as entities mass-produced for profit/food). We worry in the digital age about living in a mirror/bubble that feeds back our own beliefs at the expense of diverse or convergent views: we have been guilty of the same sort of thing in academia, maintaining a largely instrumental view on other animals, especially farmed animals.

Marino's welcome conclusion for scholars is that "a shift in how we ask questions about chicken psychology and behavior will, undoubtedly, lead to even more accurate and richer data and a more authentic understanding of who they really are." Marino's target article identifies the research that 
enables us to better understand who these animals are outside the prevalent anthropocentric view. She concludes that chickens are communicative, social, emotional, reasoning individuals with personalities who often demonstrate boldness, vigilance, and a penchant for exploration.

Communication recommendations for animal advocates. Marino notes that we have traditionally privileged mammals over birds as part of an unfounded cognitive hierarchy that underestimates the richness of birds' capabilities. Even in animal-rights advocacy materials (such as pro-vegan leaflets and posters), mammals are featured more often than birds or fishes because activists are trying to appeal to human interests. (We primates tend to identify more with our fellow mammals.) It is important that animal activists not reinforce the notion that the species who are most like us are the most worthy: all animal species in need (including chickens, turkeys and fishes, not primarily pigs and cows) should be represented and protected (Freeman, 2014).

In my field of communication, we emphasize the role of terminology and language in conveying appropriate respect for anyone (human or nonhuman). Marino pays attention to language, using the personal pronouns "they," "he," or "she," and avoiding the objectifying pronoun "it" in describing chickens. Another term she intentionally uses with chickens is "emotion"; this conveys more depth than the conservative scientific term "affect." Consider the difference between describing a chicken as a "farm animal," "poultry," "livestock," or "protein" and describing her as a "farmed animal" or "a hen who is used for egg production." To avoid industry euphemisms in describing birds and to try instead to be more animating and accurate, I often include an action verb that makes explicit the human role in using them for an agricultural or business purpose (e.g., farmed, used, exploited, bred, sold, consumed, etc.). The hope is that this will call to mind that they could be more than fulfillers of the function we dictate for them.

Marino's target article will be a useful reference for anyone who wants to be more open-minded and curious about the ways we may have underestimated or misperceived chickens - a ubiquitous species who represents such a large part of our lives, culture, and economy, yet to whom we give so little consideration.

\section{References}

Davis, K. (2012). The mental life of chickens as observed through their social relationships. In J. A. Smith \& R. W. Mitchell (Ed.), Experiencing Animal Minds: An Anthology of Animal-Human Encounters (chapter 1), Columbia University Press.

Foucault, M. (1980). Power/Knowledge. Brighton, Sussex: The Harvester Press.

Freeman, C. P. (2014). Framing Farming: Communication Strategies for Animal Rights. NY: Rodopi Press. Marino, L. (2017). The inconvenient truth about thinking chickens. Animal Sentience, 17(1). 


\section{ANIMAL CONSCIOUSNESS}

On November 17-18, 2017, the NYU Center for Mind, Brain and Consciousness, the NYU Center for Bioethics, and NYU Animal Studies will host a conference on Animal Consciousness.

This conference will bring together philosophers and scientists to discuss questions such as: Are invertebrates conscious? Do fish feel pain? Are nonhuman mammals self-conscious? How did consciousness evolve? How does research on animal consciousness affect the ethical treatment of animals? What is the impact of issues about animal consciousness on theories of consciousness and vice versa? What are the best methods for assessing consciousness in nonhuman animals?

\section{Speakers and panelists include:}

Colin Allen (University of Pittsburgh, Department of History \& Philosophy of Science), Andrew Barron (Macquarie, Cognitive Neuroethology), Victoria Braithwaite (Penn State, Biology), Peter Carruthers (Maryland, Philosophy), Marian Dawkins (Oxford, Zoology), Dan Dennett (Tufts, Philosophy), David Edelman (San Diego, Neuroscience),

Todd Feinberg (Mt. Sinai, Neurology), Peter Godfey-Smith (Sydney, Philosophy), Lori Gruen (Wesleyan, Philosophy), Brian Hare (Duke, Evolutionary Anthropology), Stevan Harnad (Montreal, Cognitive Science), Eva Jablonka (Tel Aviv, Cohn Institute), Björn Merker (Neuroscience), Diana Reiss (Hunter,

Psychology), Peter Singer (Princeton, Philosophy), Michael Tye (Texas, Philosophy)

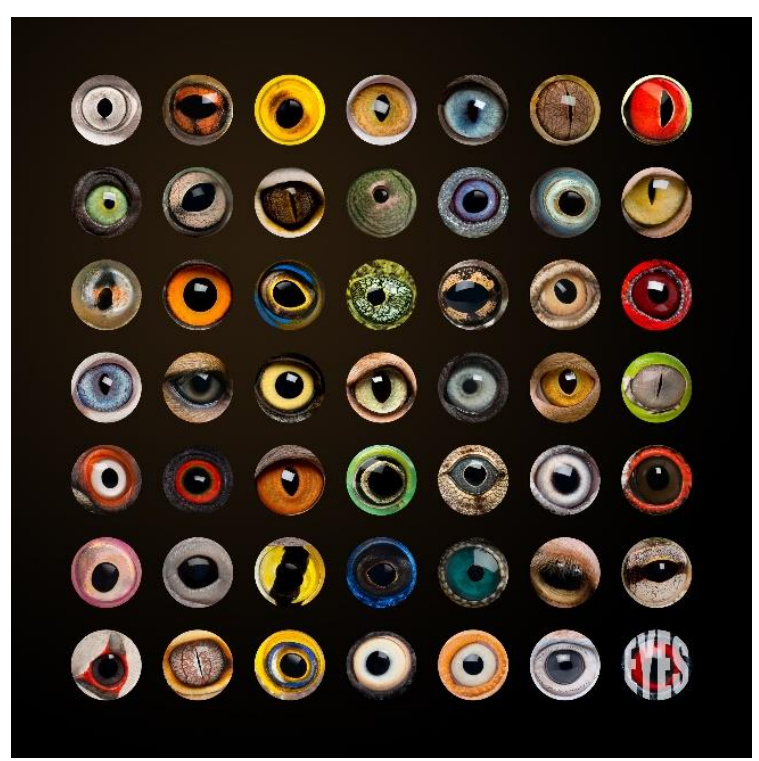

Organizers: Ned Block, David Chalmers, Dale Jamieson, S. Matthew Liao.

The conference will run from 9am on Friday November 17 to $6 \mathrm{pm}$ on Saturday November 18 at the NYU Cantor Film Center (36 E 8th St).

Friday sessions will include "Invertebrates and the evolution of consciousness", "Do fish feel pain?", and "Animal consciousness and ethics".

Saturday sessions will include "Animal self-consciousness", "Animal consciousness and theories of consciousness", and a panel discussion.

A detailed schedule will be circulated closer to the conference date.

Registration is free but required.

\section{Register here.}

\section{See also the conference website}

